\title{
Healthy eating at school: consensus among experts
}

\section{Alimentação saudável no ambiente escolar: consenso entre especialistas}

\author{
Rafaella Guimarães Moraes CAMARGO \\ Simone CAIVANO² \\ Daniel Henrique BANDONI ${ }^{3}$ \\ Semíramis Martins Álvares DOMENE ${ }^{4}$
}

\section{A B S T R A C T}

\section{Objective}

To identify attributes that promote healthy eating in order to support a study for the Quality Index for School Meal Menus content validity.

\section{Methods}

This study used the Delphi technique to consult school nutrition experts in Brazil. These experts were selected among the authors of articles published between 2010 and 2015 that were identified by searching the Web of Science database, using the keywords 'school feeding', 'school nutrition program', and 'school food program', as well as the authors of official documents on this topic. The Likert method was used to record respondent perceptions in two analytical dimensions: foods that are part of a healthy menu for school feeding, and composition of an indicator of nutritional quality for school feeding menus.

\section{Results}

Most respondents ( $n=27)$ were affiliated with public institutions $(92.59 \%)$ and had over six years of experience in the area $(70.36 \%)$. Assertions resulted in consensus according to the analysis criteria. A consensus was established for fresh food, fruits and vegetables, dairy products, beans, meat and eggs, and a schedule compatible with the meal as promoters of healthy eating, and processed foods, sweets, and fat excess as risk attributes.

\footnotetext{
1 Universidade Federal de São Paulo. Instituto Saúde e Sociedade. Programa de Pós-Graduação Alimentos, Nutrição e Saúde. Campus Baixada Santista, R. Silva Jardim, 136, 11015-020, Santos, SP, Brasil. Correspondência para/Correspondence to: RGM CAMARGO. E-mail: <raguimanutri@gmail.com>.

2 Universidade Federal de São Paulo. Instituto Saúde e Sociedade. Programa de Pós-Graduação Alimentos, Nutrição e Saúde. Santos, SP, Brasil.

${ }^{3}$ Universidade Federal de São Paulo. Instituto Saúde e Sociedade. Departamento de Saúde, Clínica e Instituições. Santos, SP, Brasil.

${ }^{4}$ Universidade Federal de São Paulo. Instituto Saúde e Sociedade. Departamento de Políticas Públicas e Saúde Coletiva. Santos, SP, Brasil.
} 


\section{Conclusion}

Since a consensus was not reached in the first round, there is a need to broaden the debate on issues related to foods rich in sugar, replacement of meals by sweets, and foods rich in fat.

Keywords: Consensus. Menu planning. Public policies. School feeding.

\section{RE S U M O}

\section{Objetivo}

Identificar atributos promotores de alimentação saudável para subsidiar estudo para validação de conteúdo do Indicador de Qualidade para Cardápios da Alimentação Escolar.

\section{Métodos}

O estudo empregou a técnica Delphi para consultar especialistas em alimentação escolar no Brasil. Estes foram selecionados entre autores de artigos publicados entre 2010 e 2015, identificados por busca na base de dados Web of Science empregando-se as palavras-chave: 'school feeding', 'school nutrition program' e 'school food program' e que tivessem publicado documentos oficiais da área. O método Likert foi empregado para registrar a percepção dos entrevistados sobre duas dimensões de análise: alimentos que fazem parte de um cardápio saudável para a alimentação escolar e composição de um indicador de qualidade nutricional para cardápios da alimentação escolar.

\section{Resultados}

A maioria dos entrevistados ( $n=27$ ) está vinculada a instituições públicas $(92,59 \%)$ e tem mais de seis anos de experiência na área (70,36\%). As asserções resultaram em consenso segundo os critérios de análise. Foi estabelecido consenso para alimentos in natura, frutas, verduras e legumes, leite e derivados, leguminosas, carnes e ovos e horário compativel com a refeição como promotores de alimentação saudável; alimentos processados, doces e gorduras em excesso como atributos de risco.

\section{Conclusão}

Há necessidade de ampliar o debate sobre temas relativos a alimentos ricos em açúcar, doces no lugar das refeições e alimentos ricos em gordura, tendo em vista que não geraram consenso na primeira rodada.

Palavras-chave: Consenso. Planejamento de cardápio. Políticas públicas. Alimentação escolar.

\section{INTRODUCTION}

Currently, the Brazilian population has a high proportion of overweight and obese individuals; this problem has been exacerbated by the eating habits of children. Population studies show a low consumption of healthy foods such as beans, fruits, vegetables, and dairy products and a high consumption of processed and ultraprocessed foods at this stage of life ${ }^{1-2}$.

The Programa Nacional de Alimentação Escolar (PNAE - National School Meal Program) is the oldest and largest food and nutrition program in Brazil. It serves all students in basic education and contributes to learning, growth, and school performance in addition to stimulating the biopsychosocial development of children ${ }^{3}$. The quality of school meals in Brazil has progressively improved following deployment of initiatives such as the transition of the food supply as a requirement to purchase food produced by family farms ${ }^{4}$, which have impacted on school menus. In this context, the PNAE plays an important role in the promotion of healthy eating ${ }^{5}$ through food and nutrition educational activities and meal provision. Menu planning should be in accordance with established legal parameters that provide the mandatory supply of fruit and vegetables, ban the purchase of sugary drinks with low nutritional value, and restrict the purchase of ultra-processed foods ${ }^{3}$.

In order to determine their effectiveness, indicators have been developed to monitor and evaluate programs, given the scarcity of studies 
assessing the impact of nutrition programs in Brazil. These indicators provide subsidies so that decision makers can plan investments, redesign programs, and strengthen mechanisms for policies associated with social control ${ }^{6}$.

However, few indicators have been developed to evaluate the quality of school nutrition in Brazil. A literature review identified only two instruments for this purpose: the Avaliação Qualitativa das Preparações do Cardápio Escolar (AQPC-Escola, Qualitative Evaluation of Menu Components for Schools) tool, whose theoretical references originate from the 2006 Guia Alimentar para População Brasileira (GAPB, Food Guide for the Brazilian Population) and Resolution $n^{\circ}$ 38, 20097; and the Indicador de Qualidade para Cardápios da Alimentação Escolar (IQCAE, Quality Index for School Feeding Menus), developed to evaluate menus in municipalities competing for the Efficient Manager of School Food award ${ }^{4}$. However, neither tool has been validated. The IQCAE scores and components were designed to promote menus that include important foods to supply nutrients and bioactive compounds over those menus containing products with low nutritional density or that pose health risks when consumed frequently ${ }^{8-10}$.

Several methodological approaches are used to assess the validity of an instrument in order to evaluate precision as well as ability to measure its intended target. Content validation evaluates the alignment of the items that make up the instrument to a theoretical framework; these items are organized on the basis of consultation with experts on the subject in question ${ }^{11}$.

Given the lack of validated instruments to assess the quality of food served to children in basic education in our country, this study aimed to consult experts in the field of school feeding in order to identify the attributes associated with promoting healthy food in order to support content validation of the IQCAE based on a consensus on 'Healthy eating' and 'Quality index for school feeding menus'.

\section{METHOD S}

In order to create the panel of experts consulted in this study, nutritionists who had published articles from April 2010 to November 2015 were selected by searching the Web of Science database using the keywords 'school feeding', 'school nutrition program', and 'school food program', in addition to 'Brazil' as the study location. The education of authors in nutrition was confirmed by consulting the Lattes Platform a repository of curriculums of the National Council for Scientific and Technological Development. Nutritionists who were authors of official documents of the Ministry of Health and Education regarding school meals and textbooks developed by the Collaborating Centers in School Food and Nutrition were also included. To identify the electronic addresses of these experts, we used the Google search engine and the Lattes Platform.

The instrument used in this study was constructed based on IQCAE ${ }^{4}$ components (Chart 1 , then organized into two analytical dimensions composed of 16 assertions (Chart 2) and an open question ("Please point out themes and/or issues that were not addressed herein and that you feel are important to building a consensus on 'Healthy eating' and 'Quality' index for school meal menus"12). Equivalent assertions were proposed in order to confirm the consistency of their responses (probe).

Chart 1. Components of the Quality Index for School Meal Menus. Brazil, 20164.

\begin{tabular}{ll}
\hline \multicolumn{2}{c}{ Components evaluated daily } \\
\hline 1 & Grains/tubers \\
2 & Beans \\
3 & Vegetables \\
4 & Fruits \\
5 & Meat and eggs \\
6 & Milk/cheese/yogurt \\
7 & Snack or lunch compatible with meal time \\
8 & Eating sweets as a meal \\
9 & Processed meats and sausages \\
\hline & $\quad$ Components evaluated weekly \\
\hline 10 & Eating sweets as dessert \\
11 & Ultra-processed foods \\
12 & Another food group served to students \\
\hline
\end{tabular}


Chart 2. Analysis tool for developing a consensus regarding 'Healthy food' and 'Quality index for school food menus', organized by themes. Brazil, 2016

\begin{tabular}{|c|c|c|}
\hline \multirow{2}{*}{ Theme } & \multicolumn{2}{|r|}{ Assertions } \\
\hline & $\mathrm{n}$ & Description \\
\hline \multirow[t]{2}{*}{ Natural and minimally processed foods } & 1 & A healthy diet is composed mostly of foods in their natural state. ${ }^{\text {a }}$ \\
\hline & 9 & $\begin{array}{l}\text { Regular consumption of fruits, vegetables, cereals, meat, milk, and dairy products } \\
\text { supports a healthy diet. }{ }^{\text {a }}\end{array}$ \\
\hline \multirow[t]{4}{*}{ Formulated/processed foods } & 3 & $\begin{array}{l}\text { Based on their level of processing, processed cookies belong in the formulated foods } \\
\text { group. }{ }^{\text {a }}\end{array}$ \\
\hline & 3 & A healthy diet does not contain foods with a low degree of processing. ${ }^{\mathbf{b}}$ \\
\hline & 4 & $\begin{array}{l}\text { Characteristics of margarine production justify its classification as a formulated/ultra- } \\
\text { processed food. }{ }^{\text {a }}\end{array}$ \\
\hline & 5 & A daily supply of formulated/ultra-processed foods is not adequate. ${ }^{a}$ \\
\hline Consumption of beans (Legumes) & 6 & $\begin{array}{l}\text { For the Brazilian diet, it is important to value the consumption of beans and other } \\
\text { legumes. }{ }^{\text {a }}\end{array}$ \\
\hline Meats and eggs & 13 & Considering the school meal, the daily presence of meat or eggs is suitable. ${ }^{a}$ \\
\hline Sausage & 7 & Daily supply of sausage is not appropriate. ${ }^{\text {a }}$ \\
\hline Foods rich in sugar & 10 & $\begin{array}{l}\text { Foods with high content of sugar (soft drinks, chocolates, ice cream, or stuffed cookies) } \\
\text { can be part of healthy eating if consumption is occasional and in small quantities. }{ }^{{ }^{2}} \\
\text { The offer of a sweet or dessert as a meal is inadequate. }{ }^{a}\end{array}$ \\
\hline Timing of meals & $\begin{array}{l}12 \\
14\end{array}$ & $\begin{array}{l}\text { Lunch-type meals can be served until 10:30 AM. }{ }^{\mathbf{b}} \\
\text { Snack-type meals can be served between 10:30 AM and 2:30 PM. }\end{array}$ \\
\hline Foods rich in fat & 11 & Foods rich in fat, when consumed in moderation, can be part of the diet. ${ }^{a}$ \\
\hline Construction of a quality indicator & 16 & $\begin{array}{l}\text { The criteria for building a quality indicator for school lunch menus should be stricter } \\
\text { for foods high in fat or sugar, given the risks associated with their consumption. }{ }^{\text {a }} \\
\text { A quality indicator for school meal menus, in addition to being a support tool for } \\
\text { dietitians, can also be used as a tool for nutritional care actions and promotion of food } \\
\text { security and nutrition. }{ }^{\text {a }}\end{array}$ \\
\hline
\end{tabular}

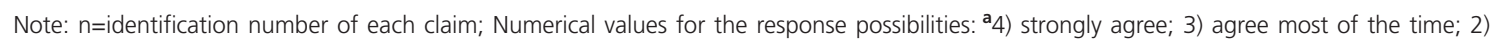
disagree most of the time; 1) strongly disagree; ${ }^{\mathbf{b}}$ 1) agree completely; 2 ) agree most of the time; 3 ) disagree most of the time; 4) strongly disagree.

Dimension 1): Foods that are part of a healthy menu for school feeding. Assertions: 1, $3,5,7,9,11,13$, and 15 .

Dimension 2): Composition of an indicator of nutritional quality for school feeding menus. Assertions: 2, 4, 6, 8, 10, 12, 14, and 16 .

The Likert Method was used to evaluate the perception of experts regarding healthy eating in schools ${ }^{13}$. The assignment of numerical values to responses was distributed between full agreement and full disagreement, with intermediate terms of inclined to agree and inclined to disagree. To build the consensus, we used the Delphi technique ${ }^{14,15}$ in two rounds.

The experts were asked to read an introductory text in order to understand the method used and the concepts and themes that were discussed during the study. They were also provided an Informed Consent Form.

Four analyses were combined to define consensus in order to ensure the results obtained for each of the assertions:

1. Scoring of each assertion: the average value was used for verification of data behavior and its dispersion ${ }^{12,13,16}$, based on the following definitions:

From 1.00 to 1.99 points: Poor perception of the evaluated object, which implied the necessity for changes or substitutions.

From 2.00 to 2.99 points: The perception indicates the need for adjustments in the assessed object, but an overall positive perception of its implementation. 
From 3.00 to 4.00 points: A positive perception of the evaluated object.

2. Standard Deviation: $<1.5$ points.

3. Frequency Distribution of Responses: at least $51 \%$ of specialists.

4. Interquartile differences ${ }^{12,16}:>1$; if $=1$, the percentage of responses 3-4>60\%.

The instrument was pre-tested by two researchers of school nutrition to adjust phraseology and improve each of the claims. This study was approved by the Ethics Committee of Universidade Federal de São Paulo (Federal University of São Paulo, CAAE $n^{\circ}$ 42685615.1.0000.5505). The experts received study clarification by email along with a link to access the survey instrument through Question Pro software.

\section{RESULTS AND DISCUSSION}

\section{Experts profile}

Of the 94 experts invited to participate in the study, 27 responded to the first round; of these, $18(66.7 \%)$ responded to the second round, corresponding to a satisfactory expert response rate $(28.0 \%)$ that was comparable to that obtained in other studies of the same nature. It should also be noted that the questionnaires were sent to nutritionists throughout the country $2,16,17$.

Of the total participants, $92.6 \%$ were affiliated with public institutions; $37.0 \%$ belong to the South Region, $22.2 \%$ to the Southeast and $29.6 \%$ to the Midwest. The Northeast (7.4\%) and North (3.7\%) Regions also contributed with answers. All respondents reported having experience in School Feeding area: $29.6 \%$ had between one and five years of experience; $55.6 \%$ had between six and ten, and $14.8 \%$ had over 15 years.

Over $70.0 \%$ of respondents rated their training in School Feeding area during their education as inadequate (66.7\%) or very poor $(7.4 \%)$. Only $25.9 \%$ considered their training to be adequate, which shows the perception of an insufficient approach to the nutrition in undergraduation courses of Brazil'17,18.

Regarding experience in the subject, $37.0 \%$ of researchers believed themselves to be highly qualified; $55.6 \%$ to have proper qualifications and $7.4 \%$ were poorly qualified. The highest degree among the researchers was postdoctorate $(3.7 \%)$; $48.1 \%$ achieved a doctorate; $40.7 \%$ had a masters degree, and $7.4 \%$ had undergraduate degrees. A study that examined the nutritionist profession in Brazil reported that, over 70 years, only $2.4 \%$ and $9.4 \%$ of the professionals were in a university program or had doctorate or master's degrees, respectively. Our findings show that the respondents had experience in the field, thus supporting our selection criteria for the identification of experts. However, there is a need to qualify the training for school nutrition area during undergraduation, considering the lack of educational experience reported by the majority of the experts; this deficit in nutrition courses has been previously identified $^{18}$.

\section{First round}

Two rounds of feedback and review of responses were performed to consolidate the consensus, as described in similar studies ${ }^{16}$. The dimensions analyzed reached consensus with an average of 3.3 points $( \pm 0.6)$ and 3.42 points $( \pm 0.4)$ for 'foods that are part of a healthy menu for school feeding' and 'composition of an indicator of nutritional quality for school feeding menus', respectively. Table 1 shows the analysis used to establish the consensus for Dimensions 1 and 2 . Assertion numbers 10, 11, and 15 did not reach a consensus in the first round and were presented to the experts again in the second round, accompanied by a theoretical foundation so that it was possible to establish a consensus. 
Table 1. Consensus of two study dimensions: average points, standard deviations, percent frequency of positive perception, range and differences in interquartile ranges (Q3-Q1) for each assertion. Brazil, 2016.

\begin{tabular}{|c|c|c|c|c|c|c|c|c|c|c|c|c|}
\hline \multirow{3}{*}{ Assertions } & \multicolumn{12}{|c|}{ Round } \\
\hline & \multicolumn{2}{|c|}{ Average points } & \multicolumn{2}{|c|}{$\begin{array}{l}\text { Standard } \\
\text { deviation }\end{array}$} & \multicolumn{2}{|c|}{$\begin{array}{l}\text { Frequency in } \\
\text { consensus (\%) }\end{array}$} & \multicolumn{2}{|c|}{ Q1 } & \multicolumn{2}{|c|}{ Q3 } & \multicolumn{2}{|c|}{$\mathrm{Q}=\mathrm{Q} 3-\mathrm{Q} 1$} \\
\hline & $1^{\mathrm{a}}$ & $2^{\mathrm{a}}$ & $1^{\mathrm{a}}$ & $2^{\mathrm{a}}$ & $1^{\text {a }}$ & $2^{\mathrm{a}}$ & $1^{\mathrm{a}}$ & $2^{\mathrm{a}}$ & $1^{\mathrm{a}}$ & $2^{\mathrm{a}}$ & $1^{\text {a }}$ & $2^{a}$ \\
\hline \multicolumn{13}{|c|}{ Dimension I - Foods that are part of a healthy menu for school feeding } \\
\hline 1 & 3.6 & - & 0.5 & - & 100.0 & - & 3.0 & - & 4.0 & - & 1.0 & - \\
\hline 3 & 3.3 & - & 0.9 & - & 74.1 & - & 3.0 & - & 4.0 & - & 1.0 & - \\
\hline 5 & 3.1 & - & 0.8 & - & 77.8 & - & 3.0 & - & 4.0 & - & 1.0 & - \\
\hline 7 & 3.7 & - & 0.5 & - & 96.3 & - & 4.0 & - & 4.0 & - & 0.0 & - \\
\hline 9 & 3.7 & - & 0.5 & - & 100 & - & 3.0 & - & 4.0 & - & 1.0 & - \\
\hline 11 & $2.7^{\star}$ & 3.2 & 0.9 & 0.9 & 66.7 & 66.7 & 2.0 & 3.0 & 3.0 & 4.0 & 1.0 & 1.0 \\
\hline 13 & 3.0 & - & 0.8 & - & 77.8 & - & 3.0 & - & 4.0 & - & 1.0 & - \\
\hline 15 & 3.2 & 3.6 & 0.9 & 0.8 & 74.1 & 74.1 & 2.5 & 3.3 & 4.0 & 4.0 & $1.5^{*}$ & 0.8 \\
\hline \multicolumn{13}{|c|}{ Dimension II - Composition of an indicator of nutritional quality of school feeding menus } \\
\hline 2 & 3.4 & - & 0.6 & - & 96.3 & - & 3.0 & - & 4.0 & - & 1.0 & - \\
\hline 4 & 3.7 & - & 0.6 & - & 92.6 & - & 3.5 & - & 4.0 & - & 0.5 & - \\
\hline 6 & 4.0 & - & 0.2 & - & 100.0 & - & 4.0 & - & 4.0 & - & 0.0 & - \\
\hline 8 & 3.6 & - & 0.7 & - & 96.3 & - & 3.0 & - & 4.0 & - & 1.0 & - \\
\hline 10 & $2.7^{*}$ & 3.2 & 1.0 & 0.8 & 59.3 & 59.3 & 2.0 & 3.0 & 3.5 & 4.0 & $1.5^{*}$ & 1.0 \\
\hline 12 & 3.1 & - & 0.7 & - & 85.2 & - & 3.0 & - & 4.0 & - & 1.0 & - \\
\hline 14 & 3.0 & - & 0.8 & - & 85.2 & - & 3.0 & - & 3.0 & - & 0.0 & - \\
\hline 16 & 3.8 & - & 0.5 & - & 96.3 & - & 4.0 & - & 4.0 & - & 0.0 & - \\
\hline
\end{tabular}

Note: *Assertions that resulted in consensus only in the second round.

\section{Second round}

The experts received the results of the first round, including the results for each assertion, as well as the theoretical basis for the suggestions that were issued during the first round. These results were grouped into thematic blocks already included in the indicator. Other suggestions from the experts and not yet included in the indicator were used as research material for future study for improvement of the IQCAE. At the end of the second round, the experts received the overall result of the consensus. The two dimensions analyzed reached a consensus with an average of 3.4 points $( \pm 0.3)$ for 'foods that are part of a healthy menu for school feeding' and 3.5 points $( \pm 0.3)$ for 'composition of an indicator of nutritional quality for school feeding menus'.

Consensus was not reached in the first round for assertion 10 (Foods high in sugar chocolates, candies preparations or stuffed cookies - can be part of a healthy diet, if consumption is not frequent and in small quantities), based on the criteria of average points (2.7) and an interquartile range greater than 1 (1.5). Based on the following theoretical basis:

The consumption of foods rich in sugar harms a balanced diet due to a high glycemic index, low nutrient content, and a lower consumption of foods with high nutritional density ${ }^{19}$; in the context of school nutrition, the possible use of sweet desserts is compatible with dimensions associated with food and eating, celebrations, and sensory satisfaction. The use of foods with sugar in quantities not exceeding $10 \%$ of total energy value is accordance to the National School Meal Program guidelines ${ }^{3}$.

consensus for all criteria was obtained in the second round (interquartile range $=1.0$; percentage of respondents with positive perception $=59.3 \%$; average $=3.2, \pm 0.8$ ). 
According to Giannarou \& Zervas ${ }^{16}$, percentages above $51.0 \%$ are sufficient to sustain the consensus for the assertion. Like the IQCAE, the AQPC-School is cautious on the subject of including sugar among 'controlled' components, which should, wherever possible, be replaced by natural foods ${ }^{7}$.

A consensus was not reached in the first round for assertion 11 (Foods rich in fat such as cream, butter, pâté and sauces; if consumption is not frequent or occurs in small quantities, it can be part of the diet) due to not meeting the criterion of average points (2.7). However, after introducing the theoretical basis:

Meta-analysis studies carried out in the 2000s show that the consumption of saturated fat in amounts of up to $10 \%$ of the total energy intake by children and adolescents are consistent with risk prevention for development of chronic diseases and guarantee growth and full development; the reduction of saturated fat supply in the diet, accompanied by increased consumption of carbohydrates, especially sugars, contributes to the synthesis of triglycerides and provides no benefit in reducing the risk for cardiovascular disease ${ }^{20}$.

consensus was reached in the second round.

This result shows how the approach for the effects of the lipid fraction of food on health remains sensitive among experts, although the most recent evidence suggest the need to revise fat intake limits and to consider the adverse risks of the simple replacement of this macronutrient by carbohydrates ${ }^{20}$.

Finally, a consensus was not reached for Assertion 15 (The offer of a sweet replacing a meal is inadequate) in the first round based on the interquartile criterion (1.5); however, after the theoretical basis:

Among the objectives of the school nutrition is the adequate and sufficient supply of energy and nutrients for children during their stay in the classroom, in addition to promote the formation of healthy eating habits ${ }^{21}$; the replacement of a meal by a sweet compromises the quality of food; this assertion has been revised to provide greater clarity about the construct that it is based upon.

the four criteria were met and a consensus was reached. The 'mealtimes' and 'processed/ formulated foods' themes were considered in assertions 12, 14 and 2, 3, 4, and 5, respectively, and the consistency of response was fulfilled (probe).

In response to the open question, 18 themes for discussion were generated, among them eight that were already included in the IQCAE and were therefore sent to the participants with a theoretical basis (Chart 3) in order to enhance their understanding of the themes of the indicator, which reinforced the subsequent study of the content validation. The others were grouped into thematic blocks and can support future studies to improve the indicator; they include organic foods ( $n=6$ participants who made the suggestion); food/regional preparations, crop and family farms food ( $n=15)$; whole foods $(n=2)$; eating together $(n=1)$; special dietary requirements $(n=1)$; preparation techniques $(n=2)$; meeting nutritional recommendations $(n=1)$; pesticides and genetically modified seeds $(n=2)$; acceptability of the preparation $(n=2)$; menu variety $(n=1)$.

Our findings confirm that the IQCAE components correspond to healthy eating markers under school nutrition were recognized by the consensus of the experts recruited for this study, including natural foods such as fruits and vegetables, meat and eggs, dairy products, beans, and grains. At the same time, the following were also confirmed as risk markers for student health: processed/formulated foods (sausages and processed meats), foods rich in fat, and foods rich in sugar. Kranz et a ${ }^{\beta 6}$ ) emphasized the importance of other elements in the diet of children, such as added sugar, total fat, linoleic and linolenic fatty acids, docosahexaenoic acid, and 
Chart 3. Theoretical basis of topics suggested by participants, grouped into thematic blocks. Brazil, 2016.

\begin{tabular}{|c|c|c|}
\hline Theme & $n$ & Theoretical foundation \\
\hline Timing of meals & 1 & $\begin{array}{l}\text { The compatibility of time in which meals are offered with the type of meal is based on culture } \\
\text { and eating habits; hypothalamic activity guides the circadian rhythm and sends signals via } \\
\text { neuroendocrine system that regulates the appetite; changes in food supply routine can disrupt } \\
\text { behaviors associated with food intake and lead to metabolic changes; it is up to nutritionists to } \\
\text { determine at which times meals are served }{ }^{3,22} \text {. The indicator under study values the offer of the } \\
\text { type of meal associated with time: snacks until 10:30AM and lunch between 10:00AM and } \\
\text { 2:00PM. }\end{array}$ \\
\hline
\end{tabular}

Consumption of fats

Iron and Vitamin A supply

Vegetables, fruits, fruit juices, dairy

Term 'formulated' at odds with the Guide for the Brazilian Population (2014)

Definition of dessert, since it is not always a sweet (excess sugar), and may also be a fruit Foods high in sodium

Population profile, different realities
2 Although the intake of saturated fat-rich foods has been associated with the development of cardiovascular diseases in the past, there is no conclusive evidence of this risk for scholars; a moderate consumption of fat balances the distribution of other nutrients, increases satiety, provides essential fatty acids, and improves the palatability of the diet; replacing food sources of fat for carbohydrates, common in diets with lipid restriction, does not provide metabolic benefits that justify this guideline ${ }^{23}$. In the indicator under study, the groups of meat and dairy products groups, important sources of fat in school meals, receive positive scores.

2 The supply of iron is guaranteed by consumption of meat, eggs, and beans, although there are differences in bioavailability of the mineral. The functions of iron include transport of oxygen and carbon dioxide for gas exchange between lungs and tissues, which is essential for the development of vital organism activities ${ }^{8}$. Anemia remains a public health problem in Brazil; the prevalence of iron deficiency anemia is above $50 \%$ among children in nursery and schools 9 . Preformed vitamin A (retinol) is found in foods of animal origin such as butter and eggs; among the carotenoids with pro-vitamin A activity is beta-carotene, which also has antioxidant activity and can be found in yellow and orange fruits and vegetables as well as dark green leafy vegetables; both play an important role in visual function, gene expression, cellular differentiation, and immunity ${ }^{24}$. The supply of these micronutrients is included in the IQCAE in the groups of meat and eggs, beans, fruits, and vegetables, which received positive scores when offered in the school menu.

5 Fruits and vegetables make up the natural food group ${ }^{25}$ provide essential micronutrients and bioactive compounds for maintaining health and reducing the risk of non-communicable chronic diseases, especially obesity. They possess anti-inflammatory and antioxidant properties, among others funcions ${ }^{10,26}$. More than half of the population in Brazil is overweight, and $15 \%$ of these are children ${ }^{27}$. Consumption of a nutritionally complete diet and healthy eating are considered prevention factors ${ }^{10}$. Dairy products are considered minimally processed foods ${ }^{25}$ and are the main food sources of calcium, an essential mineral for maintaining bone structure ${ }^{28}$. Fruit juices are considered fruit only when there is no added sugar, or when described as 'natural juice of fruit'. The IQCAE values fruits and vegetables, which are included in the 'vegetables' group. Dairy products are included in the 'cheese, milk, and yogurt' group.

1 The term 'formulated' refers to industrially-produced compounds which allow for immediate consumption or instant preparation, which may employ brief heat; in most cases, they have low nutrient density and, eventually, high energy density. These components generally contain high amounts of sodium, fat, or sugar ${ }^{29,30}$. For many years, school nutrition was characterized by the use of formulated foods due to its centralized management, making barrier to include local commerce and family farming in the supply of healthy foods to students ${ }^{5}$.

1 The statement which refers to 'a sweet or dessert as a meal'; i.e., the use of these foods to replace a meal, whether it is a sweet dessert (excess sugar) or a single fruit.

3 Foods high in sodium belongs to processed and formulated group (ready spices, processed crackers, and soups, among others). The consumption of these foods must be limited, since the processing mechanisms contribute to the loss of the nutritional composition of the main ingredients, and excess of sodium is associated with the development of chronic diseases and metabolic syndrome ${ }^{30,31}$. Sodium intake among Brazilian adolescents between 10 and 18 years is higher than recommended ${ }^{32}$. The processed of sausages and formulated foods on the menu results in decreased IQCAE.

2 The IQCAE originally was designed to evaluate shcool menus from competing for the Efficient Manager of School Meals Award, a national prize intended to promote good management in the municipalities. Among the various categories evaluated for this prize is Nutritional Efficiency ${ }^{33}$, which required the design of an instrument for this purpose published in $2011^{34}$ and adapted in $2012^{4}$. The components of the IQCAE allow for the organization of different menus; the construction of diet quality indices is supported in dietary guidelines and food guide recommendations, giving rise to levels targeted to specific objectives and populations ${ }^{35}$. 
eicosapentaenoic acid, total grains and whole grains ${ }^{36}$; however, a proposal for a quality indicator that dispenses the quantitative measurement of nutrients and enhances food is in line with recent guidelines on the subject, such as those used to develop the Food Guide for the Brazilian population ${ }^{25}$.

The components vegetables, fruit, 100\% natural fruit juice, dairy and consumption of iron, also identified in other studies ${ }^{36}$, are already considered in the indicator in this study. When proposing the AQPC-School, Veiros \& Martinelli ${ }^{7}$ classified foods into two groups: 'foods that should be recommended' and 'foods that should be controlled; ; based on this indicator, the recommended foods include fresh fruits; salads; non-starchy plants; cereals, bread, pasta and starchy vegetables; whole foods; meat and eggs; legumes; and milk and dairy products. The controlled foods include processed sweets and added sugar; sausages and processed meats; ready-to-eat processed foods; canned and preserved foods; dehydrated food concentrates or in those in powder form; breakfast cereals, cakes, and biscuits; flatulent foods and those difficult to digest; beverages with low nutritional value; preparations with repeated colors in the same meal; fried foods, fatty meats; and fatty sauces. With the exception of preparations with repeated colors and supply of flatulent food, it is clear that there is a similarity between the IQCAE assessed in the current study and AQPC-School.

The concept of healthy eating has undergone constant changes throughout the history of the science of nutrition, responding to political and social influences as well as the interests of various stakeholders in food standards, particularly in the food sector. Academic studies that explore the concept of healthy eating by offering a critical analysis of different viewpoints broaden our understanding of what 'eating well' means in contemporary times ${ }^{37}$. Although 'Healthy Eating' is a theme widely recognized by professionals, which has been recently discussed in the updated $\mathrm{GAPB}^{25}$, consolidation of this consensus required two rounds with accompanying explanations based on theoretical foundations. Therefore, this study sought to identify dimensions that contributed to validation of the content of the IQCAE, an instrument with the potential to support policy monitoring activities and food programs, including the Programa Nacional de Alimentação Escolar.

The limitations of this study result from the sampling of experts: nutritionists with publications in the field and authors of official documents did not necessarily work directly with school nutrition, even though they had academic experience in the area.

\section{CONCLUSION}

A consensus on healthy diet has been established for two major food groups: 1) foods that should be consumed daily, including fresh foods such as fruits and vegetables, meat and eggs, dairy products, beans, and grains; and 2) foods that should be eaten at low frequency, such as processed and formulated foods (sausages and processed meats), as well as foods rich in fat and sugar. The time that meals should be offered, a component included in the IQCAE was also considered relevant by the experts consulted in this study, which sets this indicator apart from other available tools.

However, the experts were unable to reach a consensus regarding other aspects of school nutrition, including foods rich in sugar, sweets replacing meals, and foods rich in fat. The theoretical foundation, however, was enough to form an understanding regarding these issues.

These results may support the proposal for mechanisms to monitor the quality of school meals by indicating the components of protection or risk that will comprise an IQCAE content validation study. Reaching a consensus on both study dimensions also showed that, despite advances in the understanding of the effects of diet on health, there are sensitive issues among experts in the field, which points to future developments in this field regarding the quality of school nutrition. 


\section{ACKNOWLEDGEMENTS}

We thank the researchers who contributed to the pilot test, helped to complete the test, and suggested new topics to be addressed, as well as the researchers who participated in this study, making it possible to generate a consensus.

\section{CONTRIBUTORS}

RGM CAMARGO participated in study conception and design, data analysis, and article writing and review. S CAIVANO, DH BANDONI e SMA DOMENE participated in study conception, design and article review.

\section{REFERENCES}

1. Instituto Brasileiro de Geografia e Estatística. Pesquisa Nacional de Saúde do Escolar 2009: avaliação do estado nutricional dos escolares do $9^{\circ}$ ano do Ensino Fundamental. Rio de Janeiro: IBGE; 2010.

2. Malta DC, Sardinha LMV, Mendes I, Barreto SM, Giatti L, Castro IRR, et al. Prevalência de fatores de risco e proteção de doenças crônicas não transmissíveis em adolescentes: resultados da Pesquisa Nacional de Saúde do Escolar (PeNSE), Brasil, 2009. Ciên Saúde Coletiva. 2010; 15(Supl. 2):3009-19.

3. Brasil. Ministério da Educação. Fundo Nacional de Desenvolvimento da Educação. Resolução CD/FNDE n² 26 de 17 de junho de 2013. Brasília: MEC; 2013.

4. Domene SMA, Belik V. Experiências de programas combinados de alimentação escolar e desenvolvimento local em São Paulo. Agroalimentaria. 2012; 18(34):57-72.

5. Peixinho AML. A trajetória do Programa Nacional de Alimentação Escolar no período de 2003-2010: relato do gestor nacional. Ciên Saúde Coletiva, 2013; 18(4):909-16.

6. Santos IS. Avaliação do impacto de programas nutricionais. Rev Nutr 2009; 22(1):141-50. http:// dx.doi.org/10.1590/S1415-52732009000100013

7. Veiros MB, Martinelli SS. Avaliação qualitativa das preparações do cardápio escolar: AQPC Escola. Nutr Pauta. 2012; 20(114):3-12.

8. Bortolini GA, Vitolo MG. Importância das práticas alimentares no primeiro ano de vida na prevenção da deficiência de ferro. Rev Nutr. 2010; 23(6):1051-62. http://dx.doi.org/10.1590/S1415-5273201000 0600011
9. Vieira RCS, Ferreira HS. Prevalência de anemia em crianças brasileiras, segundo diferentes cenários epidemiológicos. Rev Nutr. 2010; 23(3):433-44. http://dx.doi.org/10.1590/S1415-5273201000 0300011

10. Bastos DHM, Rogero MM, Arêas JAG. Mecanismos de ação de compostos bioativos dos alimentos no contexto de processos inflamatórios relacionados à obesidade. Arq Bras Endocrinol Metab. 2009; 53(5):646-56.

11. Cunha CM, Almeida Neto OP, Stackfleth R. Principais métodos de avaliação psicométrica da validade de instrumentos de medida. Rev Aten Saúde. 2014; 14(47):75-83.

12. Rayens MK, Hahn EJ. Building consensus using the policy Delphi method. Policy, Polit Nurs Pract. 2000; 4(1):308-15.

13. Brandalise LT, Bertolini GRF. Instrumentos de medição de percepção e comportamento: uma revisão. Rev Ciênc Empres. 2013; 14(1):7-34.

14. Rowe G, Wright G. The Delphi technique as a forecasting tool: Issues and analysis. Intern J Forecast. 1999; 15(4):353-75.

15. Wright JT, Giovinazzo RA. Delphi: uma ferramenta de apoio ao planejamento prospectivo. Cad Pesqu Admin. 2000; 1(12):54-65.

16. Giannarou L, Zervas E. Using Delphi technique to build consensus in practice. Int J Bus Sci Appl Manage. 2014; 9(2):65-82.

17. Recine E, Gomes RCF, Fagundes AA, Pinheiro ARO, Teixeira BA, Souza JS et al. A formação em saúde pública nos cursos de graduação de nutrição no Brasil. Rev Nutr. 2012; 25(1):21-33. http://dx.doi. org/10.1590/S1415-52732012000100003

18. Vasconcelos FAG, Calado CLA. Profissão nutricionista: 70 anos de história no Brasil. Rev Nutr. 2011; 24(4):605-17. http://dx.doi.org/10.1590/S14 15-52732011000400009

19. Song WO, Wang Y, Chung CE, Song B, Lee W, Chun OK. Is obesity development associated with dietary sugar intake in the US? Nutrition. 2012; 28(11-12):1137-41.

20. Santos RD, Gagliardi ACM, Xavier HT, Magnoni CD, Cassani R, Lottenberg AMP et al. I Diretriz sobre o consumo de gorduras e saúde cardiovascular. Arq Bras Cardiol. 2013; 100(1 Supl. 3):1-40.

21. Brasil. Ministério da Educação. Fundo Nacional de Desenvolvimento da Educação. Lei no 11.947 de 16 de junho de 2009. Dispõe sobre o atendimento da alimentação escolar e do Programa Dinheiro Direto na Escola aos alunos da Educação Básica. Brasília: MEC; 2009. 
22. Kalsbeek A, Scheer FA, Perreau-Lenz S, Fleur SE, Yi C, Fliers $E$, et al. Circadian disruption and SCN control of energy metabolism. FEBS Letters. 2011; 585:1412-26

23. O'Sullivan TA, Hafekost K, Mitrou F, Lawrence D. Food sources of saturated fat and the association with mortality: A meta-analysis. Am J Public Health. 2013; 103(9):e31-42. http://dx.doi.org/10.2105/ AJPH.2013.301492

24. Weber D, Grune T. The contribution of â-carotene to vitamin A supply of humans. Mol Nutr Food Res. 2012; 56(2):251-8.

25. Brasil. Ministério da Saúde. Secretaria de Atenção à Saúde. Guia Alimentar para a População Brasileira. Brasília: MEC; 2014.

26. Esfahani A, Wong JM, Truan J, Villa CR, Mirrahimi A, Srichaikul K, et al. Health effects of mixed fruit and vegetable concentrates: A systematic review of the clinical interventions. J Am Coll Nutr. 2011; 30(5):285-94.

27. Instituto Brasileiro de Geografia e Estatística. Pesquisa de Orçamentos Familiares 2008-2009. Antropometria e estado nutricional de crianças, adolescentes e adultos no Brasil. Rio de Janeiro: IBGE; 2010.

28. Rovira, RF. La leche y los productos lácteos: Fuentes dietéticas de cálcio. Nutr Hosp. 2015; 31(Supl. 2):1-9.

29. Martins APB, Levy RB, Claro RM, Mourabac JC, Monteiro CA. Participação crescente de produtos ultraprocessados na dieta brasileira (1987-2009). Rev Saúde Pública. 2013; 47(4):656-65.

30. Monteiro CA, Levy RB, Claro RM, Castro IRR, Cannon $\mathrm{G}$. A new classification on foods based on the extent and purpose of their processing. Cad Saúde Pública. 2010; 26(11):2039-49.

31. Steemburgo T, Dall'Alba V, Gross JL, Azevedo MJ. Fatores dietéticos e síndrome metabólica. Arq Bras Endocrinol Metab. 2007; 51(59):1425-33.

32. Veiga GV, Costa RS, Araujo MC, Souza AM, Bezerra IN, Barbosa FS, et al. Inadequação do consumo de nutrientes entre adolescentes brasileiros. Rev Saúde Pública 2013; 47(1 Supl.):212S-21S.

33. Weis B, Chaim NA, Belik V. Manual de gestão eficiente da merenda escolar. $2^{a}$ ed. São Paulo: Ação Fome Zero; 2005.

34. Domene SMA, Chaim NA, Turpin ME, Menezes F. A alimentação na Escola: uma avaliação qualitativa. In: Sawaya AL. Desnutrição, pobreza e sofrimento psíquico. São Paulo: EDUSP; 2011.

35. Barbosa RMS, Colares LGT, Soares EA. Desenvolvimento de guias alimentares em diversos países. Rev Nutr. 2008; 21(4):455-67. http://dx.doi.org/10. 1590/S1415-52732008000400010

36. Kranz S, Findeis JL, Shrestha SS. Uso do índice de qualidade da dieta infantil revisado para avaliar a dieta alimentar de pré-escolares, seus preditores sociodemográficos e sua associação com peso corporal. J Pediatri. 2008; 84(1):26-34.

37. Azevedo E. Reflexões sobre riscos e o papel da ciência na construção do conceito de alimentação saudável. Rev Nutr. 2008; 21(6):717-23. http://dx. doi.org/10.1590/S1415-52732008000600010

Received: April 13, 2016

Final version: July 5, 2016

Approved: August 24, 2016 
